\title{
RELATIONSHIP BETWEEN IMPERSONAL TRUST AND INNOVATIVE CULTURE: AN EMPIRICAL STUDY
}

\section{Katarzyna Krot ${ }^{1}$, Dagmara Lewicka²}

\footnotetext{
1 Bialystok University of Technology, Faculty of Engineering Management, Poland, ORCID: 0000-0002-7404-1724, katarzynakrot@gmail.com (corresponding author);

2 AGH University of Science and Technology, Faculty of Management, Poland, ORCID: 0000-0002-6955-7371, dagal@poczta.fm.
}

\begin{abstract}
In the contemporary economic reality, which is based on relations, the role of trust both in the intra- and inter-organisational context is growing in importance. Impersonal trust is characterized by considerable durability and forms a solid framework for developing interpersonal trust. In consequence, many researchers' attention is drawn towards practices aimed at the development of such trust. The goal of the paper is to analyse potential relations between the degree of impersonal trust and innovative culture and, in particular, to operationalise the variables, i.e. determine the dimensions of impersonal trust and innovative culture, estimate the impact of the individual dimensions of the former onto those of the latter. The survey was conducted in Poland among 630 employees of large and mediumsized enterprises. Verification of the theoretical model was performed based on structural equation modeling. The research led to the identification of dependencies between the particular dimensions of impersonal trust and innovative culture, confirming the importance of impersonal trust in the process of shaping organisational culture. Impersonal trust was recognized as a separate construct which determines the nature of innovative culture. Feeling of security has special significance at workplace because guarantees stability, durability and openness in relations, enhances creativity of staff and gives them freedom to try non-conventional solutions to problems. Organisational assurance, i.e. a conviction about the clarity of rules and principles, open communication and making staff feel they are included in organisational processes, has a weaker impact on the dimensions of innovative culture when compared to feeling of security.
\end{abstract}

Keywords: Impersonal trust, dimension of trust, innovative culture, Poland.

JEL Classification: 015, 033.

APA Style Citation: Krot, K., \& Lewicka, D. (2020). Relationship between Impersonal Trust and Innovative Culture: An Empirical Study. E\&M Economics and Management, 23(3), 82-100. https://doi.org/10.15240/tul/001/2020-3-006

\section{Introduction}

In the uncertain and volatile environment of the modern world, the role of trust is growing. A volatile business environment has forced organisations to deconstruct some of their structures and build other structures internally (Lewicka \& Rakowska, 2017). These oftenoccurring and sometimes hardly predictable transformations, trigger natural resistance and uncertainty among members of organisations and, in consequence, a need for trust is born, not only towards the staff but also towards the entire organisation, which is expected to guarantee stability and predictability (Lewicka, 2010). So far, researchers have mostly focused on interpersonal organisational trust, pointing to its role in supporting innovation (Dirks \& Ferrin, 2001; Heyns \& Jearey, 2013), often disregarding the role of impersonal trust. However, as it turns out, impersonal trust may become a serious source of competitive advantage. Trust guarantees a feeling of 
security and freedom of operation required in the context of risk connected with innovation and the uncertainty, ambiguity and complexity that accompany it (Six, 2005). For this reason, trust is necessary to generate new ideas but also to transform them into business solutions and new products. In an atmosphere of trust, employees do not waste their time controlling things, reviewing previous arrangements and agreements, do not participate in a game but are focused on creating innovation (Carolyn, 2009). Confidence that innovative ideas will be treated seriously by an enterprise is a prerequisite for their dissemination.

Recently, the role of impersonal trust is growing because interpersonal trust has been deteriorating, has become fleeting and extremely difficult to rebuild (Vanhala et al., 2011). According to Kramer (1999), impersonal trust may be permanent to the extent that it also exists when interpersonal trust is low.

An increasingly large group of researchers regard organisational culture as one of the core factors with a substantial impact on the operation of organisations, one which determines effectiveness and efficiency (Deal \& Kennedy, 1982; Yilmaz \& Ergun, 2008). Some claim that organisational culture lies at the heart of innovation (Trompenaars \& Hampden-Turner, 2004). Some researchers show that culture can support the creativity and innovation of an organisation in a number of ways, including the process of socializing, communicated values, artefacts, practices and procedures. Motivation and decision-making by employees are largely determined by corporate culture (Guiso et al., 2015). This means that organisational culture should also be treated as one of the organisational determinants of innovation (Naranjo-Valencia et al., 2010). The above arguments prompt us towards the assumption that the phenomenon of innovative culture does exist (Ahmed, 1998; Dobni, 2008; Muñoz-van den Eynde et al., 2015). However, many researchers are still trying to identify the characteristics of organisational culture which support innovation, making it possible for business entities to achieve success and indicate that there are types of culture with greater potential to support innovation.

The relationship between trust (impersonal trust in particular) and organisational culture has not been studied very intensively through empirical research. For this reason, it would be interesting to develop a clearer definition of the relationship between impersonal trust and innovative culture and, moreover, to answer the question whether and to what extent, the degree of impersonal trust shapes innovative culture. So far, research has focused on attempts to demonstrate the impact of organisational trust on innovativeness (Ellonen et al., 2008; Vanhala \& Ritala, 2016). It should be remembered that there exist some difficulties with generating objective data on innovative achievements of enterprises and that the studies conducted so far have limitations arising from the fact that the measurement of the degree of innovation is often based on respondents' views. Further to the above, the authors of this paper believe that it is worthwhile to analyse innovative culture on the assumption that it is a source of values, models and stimuli for innovative attitudes and behaviours such as generating ideas, genuine acceptance of testing new approaches and solutions, tolerance for errors and mistakes, implementing initiatives and organisational solutions oriented towards supporting innovation.

Both 'impersonal trust' and 'innovative culture' are relatively new terms, not thoroughly researched yet, but promising as subjects of scientific inquiry. The studies conducted thus far have revealed a dependence between general trust and innovation (Semerciöz et al., 2011; Ellonen et al., 2008). There is a cognitive gap regarding factors based on impersonal trust which stimulate the development of innovative culture. Bearing in mind the special role of impersonal trust as a framework for organisational processes, it is worth investigating the impact of this trust on innovative cultures. Identification of the constructs of impersonal trust and innovative culture can (i) throw a spotlight on the strength of the influence of impersonal trust, and (ii) help to verify these constructs.

Therefore, this paper aims to identify the trust-related determinants of a culture of innovation, analysing and verifying the potential and possible relations between the degree of impersonal trust and innovative culture with dual goals: firstly, to operationalise the variables, i.e. determine the dimensions of impersonal trust and innovative culture and, secondly, to attempt to estimate the impact of the individual dimensions of impersonal trust onto the dimensions of innovative culture (Glińska-Neweś, 2013). 
Our study contributes to the existing body of knowledge in the following ways. Firstly, the dimensions of impersonal trust are identified. So far, little research has focused on impersonal trust, favouring interpersonal trust instead. For this reason, our research contributes to the development of investigations related to impersonal trust. Secondly, the important role of impersonal trust in the process of shaping innovative culture is proved and it is pointed out that the dimensions of this type of trust tend to have a different impact on innovative culture. Thus far, impersonal trust has usually been approached as a mediator of a relationship (Lewicka \& Krot, 2015; Vanhala \& Ritala, 2016). In this paper, its real impact on the perception of an organisational culture is demonstrated and proven. Thirdly, the research results may inspire an academic debate about the nature of the relationship between trust, including impersonal trust, innovative culture and innovation; even more so that the issue has not been the focal point of many studies.

\section{Literature Review}

\subsection{Impersonal Trust}

In the literature on organisational trust, interpersonal trust, which applies to the relationship among an employee's line managers and colleagues, is differentiated from impersonal (institutional) trust (Bahman \& Ipken, 2011). Trust in an organisation as a whole is how the organisation's credibility is assessed by its employees. Processes in organisations are assessed from the point of view of the potential benefits for employees and for the entire organisation (Atkinson \& Butcher, 2003). Impersonal trust is a belief that some necessary structural conditions exist which increase the probability of achieving the desired outcome (McKnight et al., 2002).

Vanhala et al. (2011) define impersonal trust as employees' expectations about the opportunities created by their employer in the employment process and the fairness of the existing procedures. With this kind of trust, employees are fully convinced of the sense and benefits of the enterprise or project in which they are involved. At the same time, it assures security and stability in a variable environment (Krot, 2010).

Ellonen et al. (2008) emphasise that impersonal trust may also be defined as trust which the members of an organisation have towards its vision and strategy, its technical and commercial competences, fair processes and its HR policy. Impersonal trust is built largely through effectiveness of management and fairness of the rules governing the operation of each level in the structure of an organisation and the entire enterprise.

Impersonal trust arises from evaluation of formal structures embedded in an organisation, such as: accreditations, certificates or licenses, which guarantee stability, security and predictability (Tschannen-Moran \& Hoy, 2000). This is why impersonal trust is comprehended in two dimensions: structural assurance and situational normality. The first one stands for the conviction that formal structures, i.e. guarantees, regulations, promises and other procedures are aimed to promote the delivery of goals (Shapiro, 1987). The second dimension, situational normality, indicates a belief that the environment of the organisation is arranged in an orderly fashion and appropriately structured, and that it promotes success possible or more probable (Lewis \& Weigert, 1985). This dimension is based on the employees' belief that the enterprise operates as planned and everything seems to be working correctly, enabling the delivery of plans. Ellonen et al. (2008) mention a third factor - vision, strategy and communication. According to Pavlou et al. (2002), the importance of these dimensions of impersonal trust changes in time. At the initial stage of building relations with an organisation, when other premises for trust are missing, structural assurance is the most important dimension supporting impersonal trust. Similarly, situational normality, at the initial stage, is of particular importance since any deviations noticed by employees may destroy the initial trust.

\subsection{Innovative Culture}

In the early 1980s, the concept of culture, derived from anthropology, began to be used in the context of organisations (Kluckhohn, 1951). Ever since, growing interest in the phenomenon of organisational culture has been observed in both organisational science (Schein, 1984; Smircich, 1983) and business practice (Deal \& Kennedy, 1982).

Organisational culture encompasses shared assumptions, core values and standards (Shein, 1985); it is defined as collective programming of the minds of people who spend time in the same 
environment (Hofstede, 1984), a pattern of one's convictions and beliefs, giving employees a purpose and providing them with rules of behaviour (Davis, 1985). Definitions of culture also imply its role as a factor affecting people's behaviour in an organisation (Armstrong, 2011). The dependence is strongly emphasised by Bjerke (2004, p. 28), who points out that culture means "basic behaviour standards, values and assumptions (convictions) which have been interpreted and given meaning in the process of interaction and which have an impact on behaviour while they are not behaviour themselves". Colguitt et al. (2002) define culture as shared social knowledge in an organisation, encompassing principles, standards and values which develop the attitudes and behaviour of staff. The impact of culture on the behaviour of participants in an organisation depends on the type of culture and its other features, e.g. its power. Organisational culture offers a common system of meanings which serves as the basis for communication and mutual understanding.

An analysis of the notion of organisational culture should also include the distinction between organisational climate and organisational culture, as these two terms are closely interrelated. The unique culture of an organisation creates a specific atmosphere, which is felt by employees and can be called 'organisational climate'. This phrase denotes the way in which employees experience organisational culture. Some researchers (e.g. Trunk Širca et al., 2013) treat climate as part of organisational culture and refer to it as "a climate for something", e.g. a climate for security, diversity, and/or innovation. As organisations tend to have many different priorities, there may be many types of climates (Schneider et al., 1994) which, interestingly, may be felt or experienced with a different intensity in the same organisation. Organisational climate is more susceptible to changes, e.g. through the activities of the top management, unlike culture, which lies outside managerial control (Alvesson, 1991) and which is not easy to change as it would take a long time and involve many coordinated actions to change it (Sułkowski \& Sikorski, 2014). According to Bjerke (2004), studies of climate make it possible to verify whether people's expectations regarding their work in a given organisation are met, which is expressed by the degree of consistency between the organization's culture and the values expressed by the employees. Climate studies disclose the root causes of some phenomena, e.g. low commitment or conservative attitudes of the staff. On the other hand, culture is about the nature of these phenomena. However, it should be remembered that there are very clear and strong links between the culture and climate of an organisation (Wallace et al., 1999).

Ahmed (1998) emphasises that culture has two components: explicit and implicit, which help to understand the method to be applied in its researching and managing. Explicit culture points out to the behavioural patterns and artefacts on the basis of which the culture manifests itself in an organisation. The implicit component of culture encompasses those values, standards, beliefs and premises which come as the basis for organisational behaviours and artefacts. Explicit culture is easier to study quantitatively than its outer layers.

When investigating the main research and analytical perspectives on organisational cultures, one must remember that they differ chiefly in terms of the origin of the factor which impacts the culture of organisations. In quantitative studies, organisational culture is treated either as an independent or dependent variable. In cross-national research and comparative management, it is usually regarded as an independent variable, i.e. an external factor which directly influences management styles and the behaviour of the members of organisations in a given country (Smircich, 1983; Hofstede, 1980; Hampden-Turner \& Trompenaars, 2001).

The other approach considers organisational culture to be dependent on other organisational factors: type of ownership, sector, branch, transaction costs, the activity of entrepreneurs, strategy leaders, mission leaders, etc. Under this approach, culture is created within organisations (Smircich, 1983). Our paper concurs with this view. Deliberate and conscious nurturing of trust towards an organisation, as well as emphasis on forming relationships based on trust, should (along with other measures taken by leaders) contribute to the gradual emergence of the desirable changes in organisational cultures.

In essence, organisational culture is tantamount to a factor which affects human behaviour and management processes in an organisation (Sydow et al., 2009). Following this assumption, a culture may also stimulate 
innovative or reactive actions of employees which represent a context for forming evaluating judgments about desirable and undesirable elements in an organisation. Many authors study dependencies between organisational culture and innovation in an organisation, pointing out strong relations between certain types of organisational culture and the degree of its innovation (Chang \& Lee, 2007; Lau \& Ngo, 2004). On this basis, the concept of innovation-supporting culture (or 'innovation culture') was created.

The concept of innovative culture is receiving increased attention from many researches (Quinn \& Cameron, 2003; Dobni, 2008). From this attention grows a need to clarify what the term 'innovation culture' means and how to study it. Much work on innovative culture has been conceptual and theoretical rather than empirical in nature, which is understandable given the difficulties and methodological challenges of measuring the dimensions of culture. The construct certainly still needs to be operationalised and measured.

As various authors created their typologies of culture, they incorporated in them dimensions which were, to an extent, associated with innovation, e.g. long-term and short-term orientation (Hofstede, 1980) or introduced innovative culture as a separate type of culture. For instance, 'adhocracy culture', described by Cameron and Quinn (2003), is a model of culture which supports innovation. Such an organisation requires rapid growth, entrepreneurship and creativity. Its members are not afraid of risk. Cohesion of an organisation stems from its inclination to experiment and introduce innovation.

From the point of view of the considerations presented in this paper, the culture of an incubator, characteristic of Silicon Valley companies, is also interesting (Trompenaars, 2010). It is an egalitarian and individual-oriented culture. The leitmotif of this type of culture is the idea that 'existence comes before an organization', which is reflected in the conviction that it is the organisation that should be used by employees as a means for self-fulfillment. They are encouraged to free themselves from routine and turn to creative activity. It is mostly creativity and initiative that count. In such organisations, hierarchy is limited to the minimum and leadership is connected with creativity, intuition and seeking opportunities. An incubator culture promotes emotional commitment to work and allows employees to find joy in the process of creation and innovation (Hampden-Turner \& Trompenaars, 2001).

A holistic and empirically verified model of innovative culture is presented by Dobni (2008, p. 551). It is defined as a multi-dimensional construct which involves:

- an innovation intention, which consists of two sub-dimensions: an innovation propensity and organisational constituency, which set out the strategic conditions for innovation;

- innovation infrastructure, which encompasses two dimensions: organisational learning, creativity and empowerment;

- innovation influence, which encompasses two dimensions: market orientation and value orientation, focusing on the processes of producing customer value;

- innovation implementation concentrating on the implementation context which involves the ability to provide pro-active support of systems and processes in favour of changes, handling uncertainty, eliminating barriers and difficulties in the process of implementing and commercialising new ideas.

According to Dobni (2008), the abovepresented model may be used for describing, diagnosing and comparing results in each dimension to identify the area of improvement to justify calling an organisation innovative.

On this basis, an innovation culture can be described as one which is founded on a deeprooted conviction about the value of innovation. The shared values within an organisation form the basis for the development of norms which legitimise certain behaviours (Katz \& Kahn, 1978). Norms are defined as expectations about behaviour or its results which are at least partially shared by a social group (O'Reilly, 1989). An innovation culture promotes such values, norms and behaviours which are oriented towards unhampered co-operation, creativity, self-reliance, free communication and discussion, sharing of knowledge and ideas, as well as mutual support and tolerance of mistakes. Among its inherent components is also orientation towards experimenting, support for new ideas, risk-taking, as well as a conviction that these attitudes and behaviours are conducive to the development of the organisation and its employees. The outcomes 
that such behaviours generate include: innovations, increased customer satisfaction and streamlining of processes. Missions, visions and strategies of organisations often specify by what values and norms they are guided. Ideally, however, these values should permeate the activities undertaken by organisations, instead of being empty declarations.

\subsection{Impersonal Trust versus Innovative Culture}

So far, few researchers have focused on impersonal trust, although it evidently plays an important and unique role in creating innovationsupporting conditions. Research into the subject leads to the conclusion that impersonal trust may have both a direct and indirect impact on innovative culture. Some authors claim that impersonal trust is a prerequisite for building interpersonal trust. Pennington et al. (2003) confirm that impersonal trust precedes other types of trust. According to other studies, this kind of trust has a strong influence on general trust in managers (Nyhan, 1999) and on trust in particular dimensions (McKnight \& Chervany, 2001). For this reason, impersonal trust seems to be a necessary background required to build trust between people in an organisation. Based on these conclusions, two hypotheses can be made:

H1: Organisational assurance has a positive and direct impact on managerial support.

H6: Feeling of security has a positive and direct impact on managerial support.

Some even claim that impersonal trust exerts a stronger impact on (product and process) innovation of companies than interpersonal trust (Semerciöz et al., 2011). It may signify that, in some cases, implementation of innovation relies more on procedural conveniences than on interpersonal relations (Atkinson \& Butcher, 2003). Employees need formal protection to take up challenges which may sometimes end in failure. With a high level impersonal trust, employees are fully convinced about the sense and benefits of the enterprise or project they intend to be involved in. At the same time, it offers them security and a degree of stability in a volatile and unpredictable environment which surrounds innovative processes.

According to research results, impersonal trust affects a series of innovative culture components such as: employee commitment and identification with the organisation (Ellonen et al., 2008), higher effectiveness and efficient communication (Shockley-Zalabak et al., 2000; Vanhala \& Ahteela, 2011), expanding collaboration (Mayer et al., 1995; Tyler, 2003) and creativity (Bidault \& Castello, 2008). As McEvily et al. (2003) state, it is a very important feature of impersonal trust that it helps build a dense, permanent and relatively compact network of cooperating persons (often from different departments or even companies). However, before interpersonal trust is built among people, impersonal trust is required. It is the bond, the binding material of the impersonal trust relationship springing from organisational procedures and rules of conduct. Based on the above, two further hypotheses have been made:

H2: Organisational assurance has a positive and direct impact on creativity.

H7: Feeling of security has a positive and direct impact on creativity.

Impersonal trust has a major bearing on knowledge processes. Employees as team members will share their knowledge to generate new knowledge if the created mechanisms facilitating and encouraging dissemination of information evoke trust (Rolland \& Chauvel, 2000). Fear, cynicism and excessive caution will suppress all knowledge-sharing (Ford, 2004). Trust helps overcome the tension between the willingness to share knowledge and its protection (Bogers, 2011). As Rolland and Chauvel (2000) claim, trust is also the most important condition for transferring knowledge. Impersonal trust has, moreover, a huge impact on knowledge codifying processes. Persons engaged in a knowledge-creating process must be convinced that their knowledge is appropriately stored and protected against those who should not have access to the knowledge and that the knowledge will be used appropriately (Ford, 2004). This is why employees may search for a third party - an organisation - to reduce uncertainty and risk and to guarantee the securing of each party to the exchange information process (Ford, 2004). In view of the above, the next two hypotheses regard risk acceptance:

H5: Organisational assurance has a positive and direct impact on risk acceptance.

H10: Feeling of security has a positive and direct impact on risk acceptance.

Lastly, it should be noted that also the skill of employing external knowledge requires the 
right procedures and organisational openness. Therefore, impersonal trust plays a significant role in this process as well (Davenport \& Prusak, 2000).

As can be seen, impersonal trust creates conditions for initiating interactions, effective communication and, in a longer perspective, for development of collaboration, building relations and knowledge-sharing. So it seems that trust strengthens innovative cultures with procedural support required in decision-making processes concerning innovation and provision of impersonal conditions for efforts in support of innovation. In addition, it also creates a feeling of security required to implement risky projects which are often innovations themselves. Four hypotheses can be proposed here:

H3: Organisational assurance has a positive and direct impact on strategic orientation towards innovation.

H4: Organisational assurance has a positive and direct impact on operational orientation towards innovation.

H8: Feeling of security has a positive and direct impact on strategic orientation towards innovation.

H9: Feeling of security has a positive and direct impact on operational orientation towards innovation.

Further to the above, we may say that there is a strong dependence between trust and innovative culture. The above reasoning is the basis for formulating the research hypotheses presented in the paper.

\section{Research Methodology}

\subsection{Research Assumptions}

The objective of the research was to verify the relationship between impersonal trust and the individual dimensions of innovative culture. The majority of the work is focused on analysing the importance of interpersonal trust in different aspects of an enterprise's operation (Zeffrane \& Connell, 2003). As can be seen, the impact of impersonal trust on innovation or other strategic objectives is equally strong or even stronger than that of interpersonal trust (Vanhala \& Ritala, 2016; Semerciöz et al., 2011). However, culture is a more complex and, consequently, ambiguous object of research. Its multidimensional character increases the complexity of the research process and makes the identification of its "structure" more problematic. What is more, its multidirectional relations with other elements of an organisation and the environment render it more difficult to analyse. Many elements and dependencies are invisible and often even unaware to us, thus hardly observable and measurable (Gadomska-Lila, 2011). For this reason, the specific objectives of the study include:

a) to identify the dimensions of impersonal trust;

b) to discuss the dimensions of impersonal trust;

c) to determine the strength and direction of the interdependence between the dimensions of impersonal trust and those of innovative culture.

It is assumed that trust is strictly connected with organisational culture; however, the nature and strength of these relationships have not been determined as yet, in particular with regard to impersonal trust. While Dobni (2008) suggests that trust is an element of innovative culture, it is not reflected in the dimensions of culture which she proposes. It should also be noted that the factor analysis conducted by the authors of this paper confirm that the dimensions of impersonal trust and innovative culture are separate constructs.

For this reason, the results presented here are among the very few attempts to demonstrate the relationship between impersonal trust and innovative culture on the basis of a large sample of employees in innovative companies.

The choice of the purpose of the research determined the scales used, i.e. the scale analysing impersonal trust and innovative culture. For more information about the scales, see Tab. 1 and attachment.

\section{Tab. 1: Authors of the constructs}

\begin{tabular}{l|l}
\multicolumn{1}{c|}{ Scale } & \multicolumn{1}{c}{ Bibliographical sources } \\
\hline Impersonal trust (14 items) & Robinson (1996), Ellonen et al.(2008) \\
\hline Innovative culture (40 items) & Dobni (2008) \\
\hline
\end{tabular}


Both scales were subject to explorative factor analysis by using the main component technique with Varimax rotation to reduce them to dimensions with higher internal homogeneity. But first, both cases were $\mathrm{K}-\mathrm{M}-\mathrm{O}$ tested to confirm the legitimacy of running the factor analysis:

- Impersonal trust: $\mathrm{KMO}$ measure $=0.923$;

- Innovative culture: $\mathrm{KMO}$ measure $=0.975$.

In the case of impersonal trust, the explorative factor analysis led to separating two dimensions: organisational assurance and feeling of security. They both have satisfactory Alfa Cronbach factors: feeling of security $=0.87$ and organisational assurance $=0.90$.

Organisational assurance ( 7 items, e.g., "if anything in my organisation is going really wrong, I am sure I will be informed about it; there is a steady flow of information in my organization") as a dimension of impersonal trust is a conviction about the clarity of rules and principles, open communication and a sense among staff that they are included in organisational processes. What is more, employees should also feel informed on an ongoing basis about everything that is happening in their organisation. In addition, high efficiency of communication processes is also an element of organisational assurance. Meanwhile, the feeling of security (5 items, e.g., "my organisation creates the best conditions for development for me; I feel safe at my workplace") is a conviction that everything in the organisation happens in a certain order, ensuring a sense of security and satisfying the essential needs of individuals, such as personal development and the ability to express their own ideas.

In the case of innovative culture, a similar approach was followed. First, the K-M-O test was run and then the dimensions to be analysed were identified in terms of their reliability. Factor analysis led to selecting five dimensions of innovative culture. For each of them, Alfa Cronbach factors reached satisfactory values:

- Managerial support - Alfa Cronbach: 0.929;

- Creativity - Alfa Cronbach: 0.900;

- Strategic orientation towards innovation Alfa Cronbach: 0.918;

- Operational orientation towards innovation - Alfa Cronbach: 0.933;

- Risk acceptance - Alfa Cronbach: 0.743.

Managerial support (5 items, e.g., "managers communicate openly their expectations regarding innovation to employees; if employees wish to look for innovative solutions, they have their managerial support") is interpreted mainly as leadership skills oriented towards implementation of innovative undertakings. Creativity of employees ( 7 items, e.g., "in my organisation, employees are expected to show initiative; Innovations stand more chance of success if employees may express nonstandard and unique solutions in their daily operation") denotes their original and innovative way of thinking and acting, as well as showing initiative at work. Attitude to risk (3 items, e.g., "in my organisation, risk is acceptable; in my organisation, employees decide about taking risk") is simply declared acceptance for participating in different risky projects. Another element contributing to the development of innovative culture - strategic orientation towards innovation (7 items, e.g., "innovations are the key values in my organisation; in my organisation, resources are flexibly redirected toward innovative activities") - refers to clear communication of values and principles related to innovative undertakings and awareness on the part of employees that innovation is crucial to the development of a company, and that it depends, to a large extent, on the use of the stakeholders' potential.

The last component of innovative culture - operational orientation towards innovation (9 items, e.g., "in my organisation, free access to information and knowledge was given; optimal conditions were created for us also to have cross-functional cooperation") refers to organisational values and conditions conducive to innovation, manifested in the daily activities of the company, such as knowledge sharing, stimulating cooperation, initiative and responsibility for company development, and appreciation of employees' personal contribution to innovation.

In the process of structuring the business model, it was assumed that both dimensions of impersonal trust: organisational assurance and feeling of security affect individual dimensions of innovative culture. Find a graphic presentation of these assumptions on Fig. 1.

The dependence between these dimensions of impersonal trust and culture allowed us to formulate 10 research hypotheses:

H1: Organisational assurance has a positive and direct impact on managerial support.

H2: Organisational assurance has a positive and direct impact on creativity. 


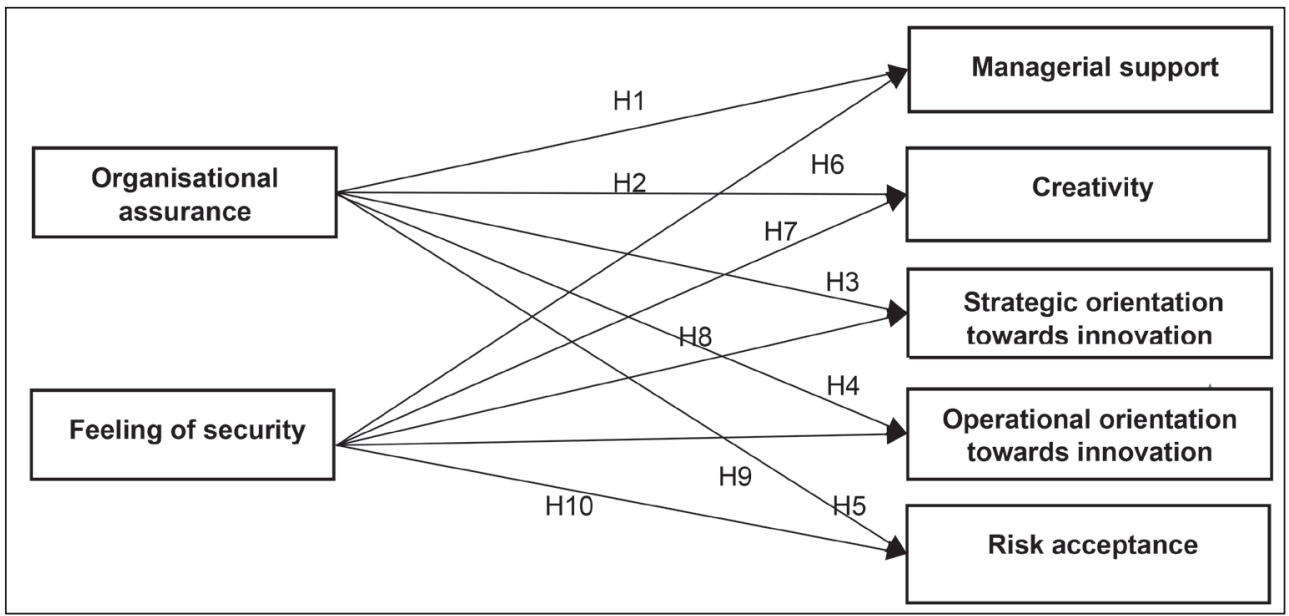

Source: own

H3: Organisational assurance has a positive and direct impact on strategic orientation towards innovation.

H4: Organisational assurance has a positive and direct impact on operational orientation towards innovation.

H5: Organisational assurance has a positive and direct impact on risk acceptance.

H6: Feeling of security has a positive and direct impact on managerial support.

H7: Feeling of security has a positive and direct impact on creativity.

H8: Feeling of security has a positive and direct impact on strategic orientation towards innovation.

H9: Feeling of security has a positive and direct impact on operational orientation towards innovation.

H10: Feeling of security has a positive and direct impact on risk acceptance.

To confirm the correctness of the proposed model, the opposite assumption was also verified, i.e. that the dimensions of innovative culture affect institutional trust. Such conceptualisation of the relationship between trust and innovative culture has not been the subject of scientific inquiry so far. Only the influence of national culture on trust has been analysed by Doney, Cannon and Mullen (1998). Analysis of the model of the influence of innovation culture on institutional trust shows that most of the relationships between the dimensions of innovation culture and the dimensions of trust have proved to be insignificant. Statistically significant dependencies can be observed only between strategic orientation to innovation and trust, although overall goodness-of-fit test results are unsatisfactory. These results confirm the validity of the models adopted by the authors.

\subsection{Sample and Data Collection}

1,769 respondents took part in the questionnaire survey. These were employees representing Polish innovative companies and had been selected on the quota basis. The studied companies were selected using the level of innovation and sector (industry or service) as the criteria. In this case, innovation was diagnosed with an additional form. The authors of the "Ranking of the Most Innovative Businesses in Poland" made an attempt to identify the characteristics of innovative companies. In their research pool, industrial companies represented $35.3 \%$ while $51.4 \%$ were service companies (including trade companies). For this reason, it was decided that - in order to keep the structure of businesses the same as in the results of the research - businesses had to be selected to be included in the sample in the 
right way. However, considering the objective of the paper, a decision was made to modify the structure of the sample, i.e. remove small enterprises (with fewer than 49 employees) from the studied group. The decision was dictated by the results of earlier analyses, which clearly showed the specific character of small entities, stemming from the very nature of impersonal trust. Because of the small number of employees working in such businesses, they often do not have any procedures and standards while their communication is often more personalised and informal, as a result of which they report exceptionally low impersonal trust (Krot \& Lewicka, 2016).

Eventually, 630 respondents were included in the sample. They were working for large and medium-sized companies, mostly in the manufacturing sector. For the structure of the research sample, see Tab. 2. Most of the members of the sample were persons under 45 years old and with professional experience reaching 8 years. 50\% are full-time employees, mainly with secondary or higher education.

\section{Research Results}

The descriptive statistics for the all the dimensions are reported in Tab. 3.

Structural equation modelling (SEM), which is a linear cross-sectional statistical modelling technique that includes path analysis and regression analysis, was applied to verify the theoretical model. Because SEM is mostly used to determine whether a model is valid rather than to 'find' a suitable model, it is the most applicable statistical method to validate the proposed model (Fig. 1). This is where theory plays an important role in justifying the model (Rodríguez \& Pérez Gutiérrez, 2007).

To construct a model of the relationship between impersonal trust and innovative culture, the authors applied the maximum likelihood (ML) estimation method. The ML function is a structured means model which reflects how closely the sample mean vector is reproduced by the estimated model's mean vector. It also indicates how closely the sample covariance matrix is reproduced by the estimated model's covariance matrix. As a result, a model may fit

\section{Tab. 2: Research sample structure}

\begin{tabular}{|c|c|c|c|c|c|}
\hline & Number & $\%$ & & Number & $\%$ \\
\hline \multicolumn{3}{|c|}{ Sex } & \multicolumn{3}{|c|}{ Contract type } \\
\hline Woman & 281 & 44.7 & Open full-time contract & 311 & 50.0 \\
\hline Men & 347 & 55.3 & Term contract & 256 & 41.2 \\
\hline \multicolumn{3}{|c|}{ Age } & Probation & 33 & 5.3 \\
\hline$<25$ years & 68 & 10.9 & A temp & 19 & 3.1 \\
\hline $25-35$ & 245 & 39.2 & Part-time & 2 & 0.3 \\
\hline $36-45$ & 205 & 32.8 & Self-employed & 1 & 0.2 \\
\hline $46-55$ & 87 & 13.9 & \multicolumn{3}{|c|}{ Work experience } \\
\hline 56 and more & 20 & 3.2 & Up to 3 years & 208 & 33.9 \\
\hline \multicolumn{3}{|c|}{ Education } & $4-8$ & 215 & 35.1 \\
\hline Elementary & 11 & 1.7 & $9-13$ & 111 & 18.1 \\
\hline Vocational & 88 & 14.0 & $14-18$ & 54 & 8.8 \\
\hline secondary & 274 & 43.5 & 19 and more & 25 & 4.1 \\
\hline College/university & 246 & 39.0 & \multicolumn{3}{|c|}{ Enterprise (size) } \\
\hline Doctorate & 5 & 0.8 & 40-200 employees & 268 & 46.0 \\
\hline \multicolumn{3}{|c|}{ Sector } & 201-500 employees & 44 & 7.5 \\
\hline Manufacturing & 521 & 82.7 & \multirow{2}{*}{$500+$ employees } & \multirow{2}{*}{271} & \multirow{2}{*}{46.5} \\
\hline Service & 109 & 17.3 & & & \\
\hline
\end{tabular}




\begin{tabular}{|c|c|c|c|c|c|c|c|c|}
\hline & $\Sigma$ & சै & 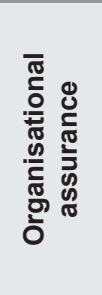 & 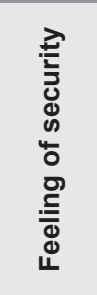 & $\begin{array}{l}\frac{t}{0} \\
\frac{0}{0} \\
\frac{0}{7} \\
\frac{0}{\pi} \\
\frac{\pi}{2} \\
\frac{0}{0} \\
\frac{\pi}{\pi} \\
\Sigma\end{array}$ & 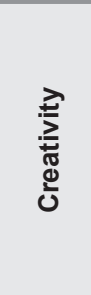 & 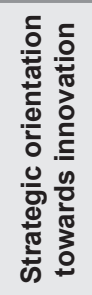 & 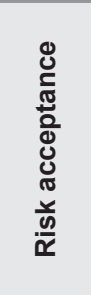 \\
\hline Organisational assurance & 24.45 & 5.79 & & & & & & \\
\hline Feeling of security & 19.07 & 4.36 & $0.71^{* *}$ & & & & & \\
\hline Managerial support & 20.98 & 5.23 & $0.65^{* *}$ & $0.66^{* *}$ & & & & \\
\hline Creativity & 25.72 & 5.47 & $0.61^{* *}$ & $0.77^{* *}$ & $0.75^{\star \star}$ & & & \\
\hline $\begin{array}{l}\text { Strategic orientation } \\
\text { towards innovation }\end{array}$ & 28.04 & 6.46 & $0.73^{* *}$ & $0.73^{* *}$ & $0.75^{\star *}$ & $0.80^{* *}$ & & \\
\hline Risk acceptance & 9.97 & 2.39 & $0.58^{* *}$ & $0.45^{* *}$ & $0.55^{* *}$ & $0.56^{* *}$ & $0.61^{* *}$ & \\
\hline $\begin{array}{l}\text { Operational orientation } \\
\text { towards innovation }\end{array}$ & 37.52 & 8.92 & $0.77^{* *}$ & $0.71^{* *}$ & $0.80^{* *}$ & $0.76^{* *}$ & $0.83^{* *}$ & $0.68^{* *}$ \\
\hline
\end{tabular}

Source: own

Note: ** Correlation significant at 0.01 bilaterally.

badly if the means are modelled poorly, or if the co-variances are modelled poorly, or both (Bentler, 1995).

Each major SEM model may be accompanied by at most two other indices of fit, such as CFI (comparative fit index) and RMSEA (root mean square error of approximation) (Bentler, 2007). The results revealed a chisquare of $4,263.44$ based on 851 degrees of freedom with a probability level of 0.000 . As the indicators show, the goodness-of-fit measures are satisfactory $\mathrm{CFI}=0.84$, RMSEA $=0.0798$, $\operatorname{HOELTER}(0.05)=136$. All paths in the model are statistically significant.

The results of Fig. 2 confirm $\mathrm{H} 1, \mathrm{H} 3, \mathrm{H} 4$ and $H 5$, which is a statistically positive and direct relationship between organisational assurance and four dimensions of innovative culture, and namely: managerial support, strategic and operational orientation towards innovation, and risk acceptance. Organisational assurance has the strongest impact on operational orientation towards innovation and the weakest for managerial support. Confidence in the organisation's procedures and the way in which the organisation acts, clarity and transparency of organisational principles ensure a stability which allows employees to take risks, creates an atmosphere of mutual co-operation between managers and employees for innovative ventures. In addition, the stability is a guarantee of the effectiveness of activities which support innovation, provides favourable conditions for creating a set of values (sharing, collaboration, etc) that are necessary in an innovative organisation.

However, H2 was not confirmed, i.e. the path between the organisational assurance and creativity was statistically insignificant.

The hypotheses related to feeling of security $(H 6, H 7, H 8, H 9$ and $H 10)$ were verified positively. Feeling of security as a dimension of impersonal trust which has a positive impact on all the dimensions of innovative culture. Feeling of security, i.e. a belief that an organisation meets its employees' needs, providing them at the same time with a sense of security, encourages creativity, risky ventures, and ensures managerial support. What is more, it further enhances employees' awareness of their key role in innovation processes and the necessity of cooperation with external partners.

In addition, the power of the impact exerted by feeling of security is definitely higher than that of organisational assurance (regression factors are definitely higher than in the case of organisational assurance). Risk acceptance 


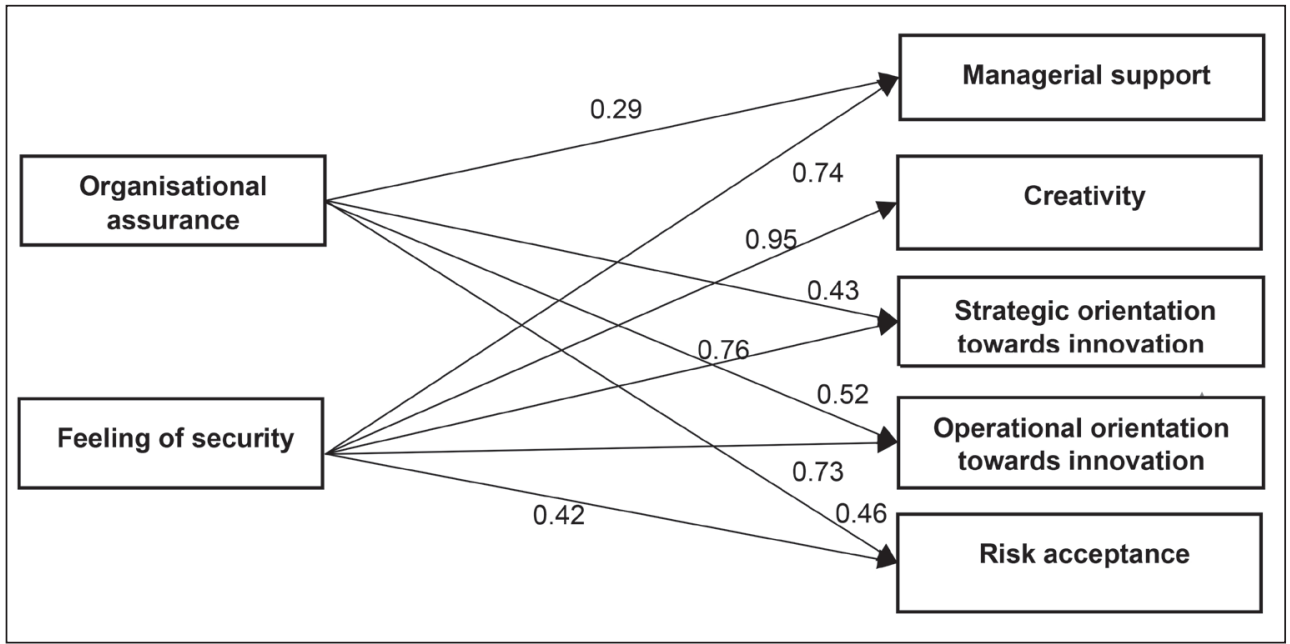

Source: own

\section{Tab. 4: Standardized regression weights}

\begin{tabular}{|c|c|c|c|c|c|c|c|}
\hline & & & Estimate & & & & Estimate \\
\hline $\begin{array}{l}\text { Managerial } \\
\text { support }\end{array}$ & $\leftarrow$ & $\begin{array}{l}\text { Organisational } \\
\text { assurance }\end{array}$ & 0.29 & Creativity & $\leftarrow$ & $\begin{array}{l}\text { Feeling } \\
\text { of security }\end{array}$ & 0.95 \\
\hline $\begin{array}{l}\text { Strategic } \\
\text { orientation } \\
\text { towards } \\
\text { innovation }\end{array}$ & $\leftarrow$ & $\begin{array}{l}\text { Organisational } \\
\text { assurance }\end{array}$ & 0.43 & $\begin{array}{l}\text { Strategic } \\
\text { orientation } \\
\text { towards } \\
\text { innovation }\end{array}$ & $\leftarrow$ & $\begin{array}{l}\text { Feeling } \\
\text { of security }\end{array}$ & 0.76 \\
\hline $\begin{array}{l}\text { Operational } \\
\text { orientation } \\
\text { towards } \\
\text { innovation }\end{array}$ & $\leftarrow$ & $\begin{array}{l}\text { Organisational } \\
\text { assurance }\end{array}$ & 0.52 & $\begin{array}{l}\text { Operational } \\
\text { orientation } \\
\text { towards } \\
\text { innovation }\end{array}$ & $\leftarrow$ & $\begin{array}{l}\text { Feeling } \\
\text { of security }\end{array}$ & 0.73 \\
\hline $\begin{array}{l}\text { Risk } \\
\text { acceptance }\end{array}$ & $\leftarrow$ & $\begin{array}{l}\text { Organisational } \\
\text { assurance }\end{array}$ & 0.46 & $\begin{array}{l}\text { Risk } \\
\text { acceptance }\end{array}$ & $\leftarrow$ & $\begin{array}{l}\text { Feeling } \\
\text { of security }\end{array}$ & 0.42 \\
\hline $\begin{array}{l}\text { Managerial } \\
\text { support }\end{array}$ & $\leftarrow$ & $\begin{array}{l}\text { Feeling of } \\
\text { security }\end{array}$ & 0.74 & & & & \\
\hline
\end{tabular}

is the only exception here. Both of these dimensions of impersonal trust have a relatively weaker impact on this aspect of innovative culture; and yet the impact of organisational assurance is stronger that the impact of feeling of security. The latter has the most powerful impact on employee creativity and strategic orientation towards innovation.

\section{Discussion and Conclusion}

\section{Discussion}

Search for innovation-stimulating factors in enterprises is an important issue for researchers and practitioners alike. Both these groups consider innovative culture and the degree of impersonal trust to be significant determinants. Approaching innovation as 
an intraorganisational process related to employee attitudes and behaviour, with strong cultural influences, an attempt was made to prove that there is a relationship between the analysed constructs. Both of them are multi-dimensional, co-dependent and difficult to operationalise. In particular, the nature of innovative culture causes many doubts in the research process. The authors of this study assume that an innovative culture consists of five dimensions (Dobni, 2008), affected by both dimensions of impersonal trust: organisational assurance and feeling of security (Elonnen et al., 2008). Impersonal trust was recognized as a separate construct which determines the nature of innovative culture. The results of the study allowed to achieve the assumed goal. The structural modelling demonstrates that both of the studied dimensions of this kind of trust strongly affect different aspects of innovative culture but feeling of security exerts a stronger and more holistic impact, i.e. it influences all the dimensions of culture, albeit with a different power. Feeling of security has special significance for stimulating creativity of the personnel (H6), while it has a relatively weaker impact on their acceptance of risk (H10). Feeling of security at workplace, which guarantees stability, durability and openness in relations, enhances creativity of staff and gives them freedom to try nonconventional solutions to problems (Von Krogh et al., 2000). Many authors emphasize that a supportive and safe climate is important for creativity (Jia et al., 2014).

On the one hand, embarking on risky enterprises requires a feeling of security and assurance which comes with trust (Neves \& Eisenberger, 2014) and, on the other hand, determination and self-confidence depend on certain personal factors along with risk propensity and perceived competence (Zuckerman \& Kuhlman, 2000). For this reason, the impact of impersonal trust in both dimensions onto risk acceptance is weaker (H5, H10). These results are, to some degree, supported by other authors. In the literature, it is commonly believed that there is a relationship between the level of trust and risk perception (Colquitt et al., 2007; Baer et al., 2018), and that the level of risk acceptance is also connected with risk perception. Thus far, the link between trust and risk in intraorganisational relationships has been analysed only in the context of interpersonal relations (Meyer et al., 1995).
The authors point out that behaviour depends on the ratio of trust levels to the degree of perceived risk, which means that whenever the level of trust exceeds the threshold of perceived risk, the trustor is willing to take risks in the relationship. The obtained result suggests that a similar dependence exists for impersonal trust and propensity for risk taking in organisations.

Organisational assurance, i.e. a conviction about the clarity of rules and principles, open communication and making staff feel they are included in organisational processes, has a weaker impact on the dimensions of innovative culture when compared to feeling of security. Importantly, hypothesis $\mathrm{H} 2$ about the impact of this dimension of trust on creativity was not confirmed. The literature does not fully support the result, as some authors point out that the system and structural solutions support creativity of staff members (Andriopoulos, 2001). However, the dependence requires further and deeper-reaching research.

\section{Conclusion}

This study gains understanding about how impersonal trust (both dimension: feeling of security and organisational assurance) influence on innovative culture. The main results is that trust strongly affect all aspects of innovative culture but feeling of security exerts a stronger and more holistic impact than organisational assurance. The feeling of security influences all the dimensions of culture, albeit with a different power. Whereas the impact of organisational assurance on creativity was not confirmed.

\section{Theoretical Contribution}

The present study addresses the question of the relationship between impersonal trust and innovative culture, which has been virtually ignored in the literature. As was indicated, the concept of innovative culture has not been widely discussed by researchers. There is, therefore, a cognitive gap regarding the factors that stimulate the development of such a culture.

Our study contributes to the elimination of this deficiency by indicating two dimensions of impersonal trust as their determinants.

The majority of studies search for determinants of innovation in enterprises. According to Škerlavaj et al. (2010), this complex issue is a combination of two constructs: (1) innovative culture and (2) innovations in 
products, services (technical innovations) and processes. A comprehensive approach to this phenomenon can result in conclusions that are insufficiently precise because the studied subconstructs have potentially varying strengths of links with the independent variables, e.g. trust and other determinants. Therefore, two possible solutions can be considered. The first one involves separating these two constructs (a culture of innovation and innovation as such) and attempting to identify the nature of the relationship that exists between each of them and the independent variables. However, the weakness of such an approach is that data regarding innovation are not readily available and that one must rely on opinion surveys, which merely gauge perceived innovation levels. The other solution involves creating a model including one of the constructs, e.g. innovation culture, in relation to independent variables. This is associated with the difficulty in distinguishing (in the opinions of respondents, without referring to hard data on innovation) between innovative culture which influences the conditions for innovative activity and the outcomes of these conditions. In this paper, the second of these two solutions is chosen. Omitting the remaining elements of innovativeness makes it possible to better understand the mechanism of the studied phenomenon, i.e. the impact of impersonal trust on innovative culture, because, as Neal and Shon (1976) observe, the choice of what to take into consideration or ignore in a model depends on the purpose of this model or, in other words, on the question which the model addresses.

Many authors have indicated the influence of perceived innovative culture on improvement of performance or its characteristics and on outcome-oriented issues (Jamrog et al., 2006). Therefore, identification of the determinants of innovative culture seems to be a significant challenge for researchers and business practitioners. This study offers an elaboration on the literature of the subject by documenting the influence of specific dimensions of impersonal trust on the particular dimensions of innovative culture. The obtained results also suggest a moderate impact of impersonal trust on the dimension of culture that stimulates employees to take risks. Unlike other research, the current study emphasises that no association exists between organisational assurance and creativity. The theoretical contribution of the paper also involves identification of and differentiation between the dimensions of a culture of innovation and impersonal trust.

\section{Managerial Implication}

Trust is a phenomenon/value of exceptional importance in the contemporary business environment. For this reason, many authors point out to the need to deliberately build organisational cultures based on trust in order to keep the position of an enterprise oriented towards competing through innovation to fully deploy the power of human potential and obtain higher efficiency of companies, thus strengthening their competitive edges. In particular, it is important to build impersonal trust, which seems to have escaped the attention of researchers and practitioners. Similarly to the introduction of changes, building trust in an organisation should start from the 'top', i.e. from impersonal trust which would provide a basis for enhancing trust between people (Pennington et al., 2003; Nyhan, 1999). This paper offers guidelines on how to build the credibility of organisations in the eyes of employees. Therefore, it proposes a set of guidelines to form trust-based relations between employees and their organisations.

Impersonal trust represents a significant value for an organisation and, in addition, it contributes to creating innovative cultures. To exist and thrive, this kind of culture needs not only deeply rooted and clearly communicated values and standards but also tools that would support it, such as systems of rewards for innovators, organisational support for innovators, codes of ethics, training aimed at developing good relations and stimulating cooperation, procedures for solving conflicts or disputes in the workplace. What is more, it takes a long-term and well-planned effort to build an innovation-supporting culture. Therefore, the paper prepares managers for changes by identifying the dimension of impersonal trust that contributes to building a specific 'element' of innovative culture. Managers encouraging employees to innovate should first of all pay attention to the feeling of security as a dimension of impersonal trust. This dimension, apart from the fact that it strongly influences innovative culture as a whole, is particularly important in supporting creatitivity. Convincing employees that their interests are protected encourages them to be creative, which is connected with 
the risk of failure and requires overcoming fear thanks to the feeling of security.

\section{Limitations and Directions for Further Research}

Undoubtedly, the limitation of the paper is the research sample, i.e. participation of large and medium-sized enterprises, which remained in the sample after small enterprises had been eliminated, in the research. Such an approach, while resulting from the objective of the research, does not guarantee that the sample is representative, thus making generalisation of the research results impossible.

Another obvious limitation is the fact of surveying employees' opinions, particularly about innovative culture. Firstly, in the literature on management, the terms: 'organisational culture' and 'organisational climate' are sometimes interchangeable (Barker, 1994). A lot of research on organisational climate was conducted in the 1980s and 1990s, but recently these topics have been far from popular. The relationships between these two constructs are not unambiguously defined and, to some extent, it is difficult to identify them precisely. Culture is interpreted as a set of assumptions, values and beliefs which give sense to an organisation and, consequently, it seems less distinctive (less prone to assumptions) than climate which comprises empirically available components such as behaviour or attitudes. Therefore, participants of an organisation find it much easier to identify its organisational climate since its elements are more accessible to experience. For the same reason, it is easier to measure.

Secondly, many researchers share the view that research with the pool of respondents recruited among employees of the researched organisation may only examine organisational climate, i.e. the external layer of a work culture (Bjerke, 2004). However, some scientists emphasise that, in fact, perceived corporate culture is analysed in qualitative research of organisational culture (Ortega-Parra \& SastreCastillo, 2013). The construct 'perceived corporate culture' seems convergent with organisational climate. So the introduction of the term 'perceived corporate culture' may be partially deemed as an attempt to reconcile the above-presented positions. In this study, in spite of the doubts discussed above, the term 'innovative culture' was used after Dobni (2008) and other contemporary researchers of the subject. As pointed out in the paper, there are a number of doubts as to the method used to analyse and study innovative culture and, more extensively, organisational culture. As a more correct solution, the authors would definitely suggest supplementing quantitative research with qualitative research. In addition, research into the matter could also go in the direction of analysing enterprises per sector.

\section{References}

Ahmed, P. K. (1998). Culture and climate for innovation. European Journal of Innovation Management, 1(1), 30-43. https://doi. org/10.1108/14601069810199131

Andriopoulos, C. (2001). Determinants of organisational creativity: a literature review. Management Decision, 39(10), 834-841. https://doi.org/10.1108/00251740110402328

Alvesson, M. (1991). Organisational symbolizm and ideology. Journal of Management Studies, 28(3), 207-226. https://doi.org/10.1111/j.1467-6486.1991.tb00945.x

Armstrong, M. (2011). Zarządzanie zasobami ludzkimi. Warszawa: Wolters Kluwer Business.

Atkinson, S., \& Butcher, D. (2003). Trust in managerial relationships. Journal of Managerial Psychology, 18(4), 282-304. https://doi. org/10.1108/02683940310473064

Baer, M., van der Werff, L., Colquitt, J., Rodell, J. B., Zipayand, K., \& Buckley, F. (2018). Trusting the "Look and Feel": Situational Normality, Situational Aesthetics, and the Perceived Trustworthiness of Organisations. Academy of Management Journal, 61(5), 17181740. https://doi.org/10.5465/amj.2016.0248

Bahman, R., \& Ipken, A. C. (2011). Understanding Institutional-based Trust Building Processes in Inter-organizational Relationships. Organization Studies, 32(2), 281-301. https:// doi.org/10.1177/0170840610397477

Barker, R. (1994). Relative utility of culture and climate analysis to an organisational change agent: an analysis of general dynamics, electronics division. International Journal of Organisational Analysis, 2(1), 68-87. https:// doi.org/10.1108/eb028802

Bentler, P. (1995). EQS Structural Equations Program Manual. Encino, CA: Multivariate Software.

Bentler, P. (2007). Can scientifically useful hypotheses be tested with correlations? 
American Psychologist, 62(8), 772-782. https:// doi.org/10.1037/0003-066x.62.8.772

Bidault, F., \& Castello, A. (2008). Trust and Creativity: Identifying the Role of Trust in Creativity-Oriented Joint-Developments (Working Paper No. 08-010). Berlin: ESMT. https://doi.org/10.2139/ssrn.1436971

Bjerke, B. (2004). Kultura a style przywództwa. Kraków: Oficyna Ekonomiczna.

Bogers, M. (2011). The Open Innovation Paradox: Knowledge Sharing and Protection in R\&D Collaborations. European Journal of Innovation Management, 14(1), 93-117. https:// doi.org/10.1108/14601061111104715

Cameron, K. S., \& Quinn, R. E. (2003). Kultura organizacyjna - diagnoza i zmiana. Kraków: Oficyna Ekonomiczna.

Cameron, K. S., \& Spreitzer, G. M. (2011). Introduction. What is positive about Positive Organisational Scholarship? In K. S. Cameron \& G. M. Spreitzer (Eds.), The Oxford Handbook of Positive Organisational Scholarship (pp. 1-14). Oxford/New York, NY: Oxford University Press. https://doi.org/10.1093/ oxfordhb/9780199734610.001.0001

Carolyn, L. (2009). Driving productivity, engagement and innovation by building trust. Human Resources, 13(5), 24-26.

Chang, S. C., \& Lee, M. S. (2007). A study on relationship among leadership, organisational culture, the operation of learning organisation and employees' job satisfaction. The Learning Organisation, 14(2), 155-185. https://doi. org/10.1108/09696470710727014

Colquitt, J. A., Scott, B. A., \& LePine, J. A. (2007). Trust, trustworthiness, and trust propensity: A meta-analytic test of their unique relationships with risk taking and job performance. Journal of Applied Psychology, 92(4), 909-927. https://doi.org/10.1037/00219010.92.4.909

Colquitt, J. A., Noe, R. A., \& Jackson, C. L. (2002). Justice in teams: Antecedents and consequences of procedural justice climate. Personnel Psychology, 55(1), 83-109. https://doi.org/10.1111/j.1744-6570.2002.tb00104.x

Davenport, T. H., \& Prusak, L. (2000). Working knowledge: How organisations manage what they know. Boston, MA: Harvard Business School Press.

Davis, T. (1985). Managing Culture at the Bottom. In R. H. Kilmann, M. J. Saxton, \& R. Serpa (Eds.), Gaining Control of the Corporate Culture. San Francisco, CA: Jossey-Bass.
Deal, T. E. \& Kennedy, A. A. (1982). Corporate Cultures: The Rites and Rituals of Corporate Life. London: Penguin Books.

Dirks, K. T., \& Ferrin, D. L. (2001). The role of trust in organizational settings. Organization Science, 12(4), 450-467. https://doi.org/10.1287/orsc.12.4.450.10640

Dirks, K. T., \& Ferrin, D. L. (2002). Trust in leadership: meta-analytic findings and implications for research and practice. Journal of Applied Psychology, 87(4), 611-628. https://doi.org/10.1037/0021-9010.87.4.611

Dobni, C. B. (2008). Measuring innovation culture in organisations. The development of a generalized innovation culture construct using exploratory factor analysis. European Journal of Innovation Management, 11(4), 539-559. https://doi.org/10.1108/14601060810911156

Doney, P. M., Cannon, J. P., \& Mullen, M. R. (1998). Understanding the Influence of National Culture on the Development of Trust. Academy of Management Review, 23(3), 601-620. https://doi.org/10.5465/amr.1998.926629

Ellonen, R., Blomqvist, K., \& Puumalainen, K. (2008). The role of trust in organisational innovativeness. European Journal of Innovation Management, 11(2), 160-181. https://doi. org/10.1108/14601060810869848

Ford, D. P. (2004). Trust and knowledge management: the seeds of success. In C. W. Holsapple (Ed.), Handbook on Knowledge Management (pp. 553-575). Berlin, Heidelberg: Springer-Verlag. https://doi.org/10.1007/978-3540-24746-3

Gadomska-Lila, K. (2011). Metodologia badań kultury organizacyjnej. Edukacja Ekonomistów i Menedżerów: problemy, innowacje, projekty, 21(3), 11-25. https://doi. org/10.5604/01.3001.0009.5746

García Rodríguez, N., José Sanzo Pérez, M., \& Trespalacios Gutiérrez, J. A. (2007). Interfunctional trust as a determining factor of a new product performance. European Journal of Marketing, 41(5/6), 678-702. https://doi. org/10.1108/03090560710737688

Glińska-Neweś, A. (2013). Employee interpersonal relationship. In M. J. Stankiewicz (Ed.), Positive management Managing the Key Areas of Positive Organisational Potential for Company Success (pp. 126-154). Toruń: TNOiK.

Guiso, L., Sapienza, P., \& Zingales, L. (2015). The value of corporate culture. Journal of Financial Economics, 117(1), 60-76. https://doi.org/10.3386/w19557 
Hampden-Turner, C., \& Trompenaars, F. (2001). Riding the Waves of Culture. London: John Murray Press.

Heyns, M., \& Jearey, A. (2013). Dimensionality of interpersonal trust and its relationship to innovativeness. The Journal for Transdisciplinary Research in Southern Africa, 9(1), 159-170. https://doi.org/10.4102/ td.v9i1.223

Hofstede, G. (1980). Attitudes, values and organisational culture: disentangling the concepts. Organisation Studies, 19(3), 477-493. https://doi.org/10.1177/017084069801900305

Hofstede, G. (1984). Cultures Consequences. International Differences in Work Related Values. London: Sage Publication Inc.

Jamrog, J. J. (2006). The Quest for Innovation: A Global Study of Innovation 20062016. New York, NY: American Management Association.

Jia, L., Show, J. D., Tsui, A. S., \& Park T.Y. (2014). A Social-Structural Perspective on Employee-Organisation Relationships and Team Creativity. Academy of Management Journal, 57(3), 869-891. https://doi. org/10.5465/amj.2011.0147

Katz, D., \& Kahn, R. L. (1978). The Social Psychology of Organisations. New York, NY: John Wiley and Sons.

Kluckhohn, C. (1951). The Study of Culture. In D. Lerner \& H. Dwight Lasswell (Eds.), The Policy Science (pp. 74-93). Stanford, CA: Stanford University Press.

Kramer, R. M. (1999). Trust and distrust in organisations: emerging perspectives and enduring questions. Annual Review of Psychology, 50(1), 569-598. https://doi. org/10.1146/annurev.psych.50.1.569

Krot, K. (2010). Zaufanie instytucjonalne jako społeczna determinanta innowacyjności przedsiębiorstw. In D. Lewicka (Ed.), Wyzwania dla współczesnych organizacji w warunkach konkurencyjnej gospodarki. Kraków: Wydawnictwo AGH.

Krot, K., \& Lewicka, D. (2016). Zaufanie w organizacji innowacyjnej. Warszawa: C. H. Beck.

Lau, C. M., \& Ngo, H. Y. (2004). The HR system, organisational culture, and product innovation. International Business Review, 13(6), 685-703. https://doi.org/10.1016/j. ibusrev.2004.08.001

Lewicka, D. (2010). The impact of HRM on creating proinnovative work environment.
International Journal of Innovation and Learning, 7(4), 430-449. https://doi.org/10.1504/ IJIL.2010.032932

Lewicka, D., \& Krot, K. (2015). The model of HRM-trust-commitment relationships. Industrial Management \& Data Systems, 115(8), 1457-1480. https://doi.org/10.1108/ imds-12-2014-0388

Lewicka, D., \& Rakowska, A. (2017). Calculative and affective commitment the case study of the best Polish employer Gaz Transmission Operator. Argumenta Oeconomica, 39(2), 213-235. https://doi. org/10.15611/aoe.2017.2.09

Lewis, J. D., \& Weigert, A. (1985). Trust as a social reality. Social Forces, 63(4), 967-985. https://doi.org/10.2307/2578601

Mayer, R. C., Davis, J. H., \& Schoorman, F. D. (1995). An integrative model of organisational trust. Academy of Management Review, 20(3), 709-734. https://doi.org/10.2307/258792

McEvily, B., Perrone, V., \& Zaheer, A. (2003). Trust as an Organizing Principle. Organisation Science, 14(1), 91-103. https://doi.org/10.1287/orsc.14.1.91.12814

McKnight, D. H., Choudhury, V., \& Kacmar, C. (2002). Developing and Validating Trust Measures for e-Commerce: An Integrative Typology. Information Systems Research, 13(3), 334-359. https://doi.org/10.1287/isre.13.3.334.81

McKnight, D. H., \& Chervany, N. L. (2001). Trust and Distrust Definitions: One Bite at a Time. In R. Falcone, M. Singh, \& Y. H. Tan (Eds.), Trust in Cyber-societies. Lecture Notes in Computer Science (Vol. 2246, pp. 27-54). Berlin, Heidelberg: Springer. https://doi. org/10.1007/3-540-45547-7_3

Muñoz-van den Eynde, A., CornejoCañamares, M., Diaz-Garcia, I., \& Muñoz, E. (2015). Measuring Innovation Culture: Development and Validation of a Multidimensional Questionnaire. Advances in Research, 4(2), 122141. https://doi.org/10.9734/air/2015/15533

Naranjo-Valencia, J. C., Valle, R. S., \& Jimenez, D. J. (2010). Organisational culture as determinant of product innovation. European Journal of Innovation Management, 13(4), 466-480. https://doi. org/10.1108/14601061011086294

Neal, F., \& Shone, R. (1976). Economic Model Building. London: Palgrave. https://doi. org/10.1007/978-1-349-15673-3_5

Neves, P., \& Eisenberger, R. (2014). Perceived organisational support and risk 
taking. Journal of Managerial Psychology, 29(2), 187-205. https://doi.org/10.1108/jmp-072011-0021

Nyhan, B. (1999). Building learning organisations: putting theory to the test - lessons from European companies. The European Vocational Training Journal, 16, 14-23.

O'Reilly, C. A. (1989). Corporations, Culture and Commitment: Motivation and Social Control in Organisations. California Management Review, 31(4), 9-25. https://doi. org/10.2307/41166580

Ortega-Parra, A., \& Sastre-Castillo, M. A. (2013). Impact of perceived corporate culture on organizational commitment. Management Decision, 51(5), 1071-1083. https://doi. org/10.1108/md-08-2012-0599

Pavlou, P. A., Tan, Y. H., \& Gefen, D. (2002). The Transitional Role of Institutional Trust in Online Interorganisational Relationships. In Proceedings of the 36th Hawaii International Conference on System Sciences (HICSS'03). Big Island, HI, USA. https://doi.org/10.1109/ hicss.2003.1174574

Pennington, R., Wilcox, H. D., \& Grover, V. (2003). The Role of System Trust in Business-to-Consumer Transactions. Journal of Management Information, 20(3), 197-226. https://doi.org/10.1080/07421222.2003.11045777

Robinson, S. L. (1996). Trust and breach of the psychological contract. Administrative Science Quarterly, 41(4), 574-599. https://doi. org $/ 10.2307 / 2393868$

Rolland, N., \& Chauvel, D. (2000). Knowledge transfer in strategic alliances. In C. Despres \& D. Chauvel (Eds.), Knowledge Horizons: The Present and the Promise of Knowledge Management (pp. 225-236). Boston, MA: Butterworth Heinemann. https://doi.org/10.1016/b978-0-7506-7247-4.50014-8

Schein, E. H. (1984). Coming to a New Awareness of Organisational Culture. Sloan Management Review, 25(2), 3-16.

Schein, E. H. (1985). How Culture Forms, Develops and Changes. In. R. H. Kilmann, M. J. Saxton, \& R. Serpa (Eds.), Gaining Control of the Corporate Culture. (pp. 17-43). San Francisco, CA: Jossey-Bass.

Schneider, B., Gunnarson, S. K., \& NilesJolly, K. (1994). Creating the climate and culture of success. Organisational Dynamics, 23(1), 17-29. https://doi.org/10.1016/00902616(94)90085-x
Shapiro, S. P. (1987). The Social Control of Impersonal Trust. American Journal of Sociology, 93(3), 623-658. https://doi. org/10.1086/228791

Shockley-Zalabak, P., Ellis, K., \& Winograd, G. (2000). Organisational trust: What it means, why it matters. Organisation Development Journal, 18(4), 35-48.

Semerciöz, F., Hassan, M., \& Aldemır, Z. (2011). An Empirical Study on the Role of Interpersonal and Institutional Trust in Organisational Innovativeness. International Business Research, 4(2), 125-136. https://doi. org/10.5539/ibr.v4n2p125

Smircich, L. (1983). Concepts of Culture and Organisational Analysis. Administrative Science Quarterly, 28(3), 339-358. https://doi. org/10.2307/2392246

Six, F. (2005). The Trouble with Trust: The Dynamics of Interpersonal Trust Building. Cheltenham: Edward Elgar. https://doi. org/10.4337/9781845426873

Škerlavaj, M., Song, J. H., \& Lee, Y. (2010). Organizational learning culture, innovative culture and innovations in South Korean firms. Expert Systems with Applications, 37(9), 6390-6403. https://doi.org/10.1016/j.eswa.2010.02.080

Sułkowski, Ł., \& Sikorski, C. (2014). Metody zarządzania kulturą organizacyjną. Warszawa: Difin.

Sydow, J., Schreyögg, G., \& Koch, J. (2009). Organisational path dependence: Opening the black box. Academy of Management Review, 34(4), 689-709, https://doi.org/10.5465/amr.34.4.zok689

Trompenaars, F., \& Hampden-Turner, C., (2004). Managing people across cultures. London: Capstone Publishing.

Trompenaars, F. (2010). Kultura innowacji: kreatywność pracowników a sukces firmy. Warszawa: Wolters Kluwer.

Trunk Širca, N., Babnik, K., \& Breznik, K. (2013). Towards organisational performance: Understanding human resource management climate. Industrial Management \& Data Systems, 113(3), 367-384. https://doi. org/10.1108/02635571311312668

Tschannen-Moran, M., \& Hoy, W. K. (2000). A multidisciplinary analysis of the nature, meaning, and measurement of trust. Review of Educational Research, 70(4), 547-593. https://doi.org/10.3102/00346543070004547

Tyler, T. R. (2003). Trust within organisations. Personnel Review, 32(5), 556-568. https://doi. org/10.1108/00483480310488333 


\section{Business Administration and Management}

Wallace, J., Hunt J., \& Richards, C. (1999). The relationship between organisational culture, organisational climate and managerial values. The International Journal of Public Sector Management, 12(7), 548-564. https://doi.org/10.1108/09513559910305339

Vanhala, M., \& Ahteela, R. (2011). The effect of HRM practices on impersonal organisational trust. Management Research Review, 34(8), 869-888. https://doi. org/10.1108/01409171111152493

Vanhala, M., Puumalainen, K., \& Blomqvist, K. (2011). Impersonal trust. The development of the construct and the scale. Personnel Review, 40(4), 485-513. https://doi. org/10.1108/00483481111133354

Vanhala, M., \& Ritala, P. (2016). HRM practices, impersonal trust and organisational innovativeness. Journal of Managerial Psychology, 31(1), 95-109. https://doi.org/10.1108/jmp-032013-0084
Von Krogh, G., Ichijo, K., \& Nonaka, I. (2000). Enabling Knowledge Creation. How to Unlock the Mystery of Tacit Knowledge and Release the Power of Innovation. New York, NY: Oxford University Press.

Yilmaz, C., \& Ergun, E. (2008). Organizational culture and firm effectiveness: An examination of relative effects of culture traits and the balanced culture hypothesis in an emerging economy. Journal of World Business, 43(3), 290-306. https://doi.org/10.1016/j. jwb.2008.03.019

Zeffane, R., \& Connell, J. (2003). Trust and HRM in the new millennium. The International Journal of Human Resource Management, 14(1), 3-11. https://doi.org/10.1080/09585190 210158484

Zuckerman, M., \& Kuhlman, D. M. (2000). Personality and risk-taking: Common biosocial factors. Journal of Personality, 68(6), 999-1029. https://doi.org/10.1111/1467-6494.00124 